Bảng 9: So sánh tỷ lê \% ống tủy chữ C ở răng 7 hàm trên của Martins

\begin{tabular}{|c|c|c|c|c|c|c|c|c|c|c|}
\hline Của Martins J & Không có & Loại A & Loại B1 & Loại B2 & Loại C & Loại D & Loại E1 & Loại E2 & Tống \\
\hline Số lượng & 1250 & 6 & 17 & 10 & 2 & 1 & 5 & 8 & 1299 \\
\hline Tỳ lẹ̣ \% & 96.2 & 0.5 & 1.3 & 0.8 & 0.2 & 0.1 & 0.4 & 0.6 & $100 \%$ \\
\hline \multicolumn{8}{|c|}{ Của chúng tôi } \\
\hline Số lượng & 570 & 55 & 64 & 10 & 6 & 0 & 14 & 1 & 720 \\
\hline Tỷ lệ \% & $79,2 \%$ & 7,6 & 8,9 & 1,4 & 0,8 & 0 & 1,9 & 0,1 & $100 \%$ \\
\hline
\end{tabular}

\section{KẾT LUẬN}

Số lượng chân răng 2 bên phải và trái khác biệt nhau không có ý nghĩa thống kê. Răng 7 trền thường có 3 chân $(91,25 \%)$, sau đấy là 2 chân $(6,94 \%), 1$ chân $(1,4 \%)$ và 4 chân $(0,4 \%)$. Số lượng 2 chân và 3 chân ở nữ $(5,1 \%$ và $49 \%)$ cao hơn nam ( $1,8 \%$ và $42 \%)$.

Chân gần ngoài răng 7 hàm trên chủ yếu có 1 ống tủy thẳng từ trên xuống (vertucci $\mathrm{I}$ ) chiếm $84,7 \%$, nữ $(85,5 \%)$ cao hơn nam $(83,8 \%)$. Sự khác nhau bên phải và trái không có ý nghĩa thống kê. Chân xa và chân trong chỉ có 1 ống tủy từ lỗ vào ống tủy đến chóp răng (loại I Vertucci)

Hình thái ống tủy chữ C chiếm $20,8 \%$ số răng 7 hàm trên nghiên cứu, trong đó hình thái $\mathrm{B} 1$ chiếm $8,9 \%$ và $A$ chiếm $7,6 \%$. Không khác biệt 2 bên phải trái, nhưng hay gặp ở nữ $(24,3 \%)$ hơn là ở nam $(16,6 \%)$.

LỜI CẢM ON. Chúng tôi xin cảm ơn bộ môn Răng Hàm Mặt - Trường Đại Học Y Dược ĐHQGHN, đã tạo điều kiện cơ sở vật chất và đối tượng nghiên cứu để hoàn thành đề tài.

\section{TÀI LIỆ THAM KHẢO}

1. Alamri, H.M., et al., Root canal morphology of maxillary second molars in a Saudi sub-population:
A cone beam computed tomography study. Saudi Dent J, 2020. 32(5): p. 250-254.

2. Mandana Naseri a, M.A.M.a., Yaser Safi b, Maryam Heidarnia c, Alireza and N.N. Akbarzadeh Baghban d, Root Canal Morphology of Maxillary Second Molars according to Age and Gender in a Selected Iranian Population A Cone-Beam Computed Tomography Evaluation. Iranian Endodontic Journal 2018, 2018. ;13(3):: p. 373-380.

3. Wolf, T.G., et al., Root canal morphology and configuration of 123 maxillary second molars by means of micro-CT. Int J Oral Sci, 2017. 9(1): p. 33-37.

4. VERTUCCI, F.J., Root canal morphology and its relationship to endodontic procedures. Endodontic Topics, 2005. 10, : p. 3-29.

5. Bansal, R., S. Hegde, and M.S. Astekar, Classification of Root Canal Configurations: A Review and a New Proposal of Nomenclature System for Root Canal Configuration. Journal of Clinical and Diagnostic Research, 2018.

6. Martins, J.N., et al., Prevalence and Characteristics of the Maxillary C-shaped Molar. J Endod, 2016. 42(3): p. 383-9.

7. Hiền, H.H.T., Đặc Điểm Hình Thái Chân Răng Và Ống Tủy Răng Cổi Lớn Thứ Nhất Và Thứ Hai Người Việt Nam . Luận án Tiến sĩ, trường Đại Học Y Dược TP Hồ Chí Minh, 2019.

8. J. DHAYANITHI, D.A.K., DR.M.P. BRUNDHA Variations in The Number of Roots and Root Canals in Maxillary Second Molars- A Review of Literature. Journal of Contemporary Issues in Business and Government, 2021. 27(02).

\title{
ĐÁNH GIÁ KẾT QUẢ PHẪU THUÂTT ĐĂT ĐIÊ̂N CỰC KÍCH THÍCH NÃO SÂU ĐIỀU TRI BỆNH LÝ PARKINSON VỒ CĂN TẠI BỆNH VIỆN VIỆT ĐỨC
}

\section{TÓM TẮT}

Mục tiêu: Mô tả kết qủa 10 trường hợp bệnh nhân Parkinson vô căn được điều trị bằng phẫu thuật kích thích não sâu tại Bệnh viện Việt Đức từ tháng 1 năm 2016 đến tháng 5 năm 2020. Đối tượng và

*Bệnh viện Việt Đức

Chiu trách nhiệm chính: Trân Đình Văn

Email: tranvanpttk@gmail.com

Ngày nhận bài: 12.3.2021

Ngày phản biên khoa học: 11.5 .2021

Ngày duyệt bài: 18.5.2021
Trần Đình Văn*, Đồng Văn Hệ*, Nguyễn Anh Tuấn*, Ngô Thị Huyền*, Nguyễn Mạnh Tiến*

phương pháp nghiên cứu: mô tả tiến cứu, theo dõi dọc tất cả các trường hợp được chẩn đoán Parkinson vổ căn và được phẫu thuật kích thích não sâu tại Bệnh viên Viêt Đức. Kết quả: nam giới chiếm chủ yếu (70\%), tuổi trung bình khi phẫu thuật là 60 tuổi, triệu chứng lâm sàng điển hình là rối loạn vận động, thăm dò điện sinh lý trong mổ nhận diện bước sóng của STN, kết quả cải thiên vận động qua thang điểm UPDRS đánh giá sau mổ 3 tháng -6 tháng -12 tháng đều cho thây cải thiện tốt và ổn định các triêuu chứng rối loạn vận động, giảm 25 - 50\% liều lượng levodopa, không gặp biến chứng đặc biệt nào sau mố.

Tư khoá: kích thích não sâu (deep brain 
stimulation), nhân dưới đồi (STN : subthalamus nucleus), vi điện cực (microelectrode), cộng hưởng từ $(\mathrm{CHT})$, Parkinson vồ căn.

\section{SUMMARY}

DEEP BRAIN STIMULATION IN PARKINSON IDIOPATHY DISEASE: CLINICAL AND IMAGE CHARACTERISTICS, CLINICAL OUTCOMES AT VIETDUC HOSPITAL

Objective: to study the clinical characteristics, diagnostic imaging, clinical outcomes of PD, using DBS. Subjects and Methods: prospective, crosssectional described 10 cases of PD opereted in the department of neurosurgery, Vietduc hospital from $1 / 2016$ to $5 / 2020$. Results and Conclusions: a men account for the majority (70\%), the average age of surgery is 60 years old, typical clinical symptoms are movement disorders, electrophysiological exploration intra operation to identify STN sharps, improved results mobilization through UPDRS scale, evaluated after 3 months - 6 months - 12 months, all showed good and stable improvement of movement disorders, reduced 25 - $50 \%$ of levodopa dose, no special complications post op.

Keywords: Deep brain stimulation, subthalamus nucleus, microelectrode, Magnetic resonance imaging, Parkinson idiopathy.

\section{I. ĐẶT VẤN ĐỀ}

Bệnh lý Parkinson là bệnh lý thoái hóa thần kinh thường gặp nhất sau Alzheimer, chiếm $2 \%$ dân số thế giới, thường gặp trên 60 tuổi, được mô tả lần đầu năm 1817. Bệnh lý đặc trưng bởi thoái hóa no ron dopaminergiques (DA) của phần đặc chất đen và trong thể vùi của tế bào chất (corps de Lewy) của những nơ ron tiếp nối. Bệnh tiến triển nhiêu năm. Các nhân xám trung ương (hạch nền) tạo ra các cử động chủ ý nhịp nhàng thông qua kiểm soát hoạt động của nơ ron vận động ở vỏ não và thân não. Các hạch nền này không kết nối trực tiếp với nơ ron vận động a ở tủy sống. Bệnh tiến triển nhiều năm. Biểu hiện đặc trưng nhất là: chậm vận động hoặc mất vận động, cứng đờ, run khi nghỉ ngơi, kèm rối loạn nhận thức ở giai đoạn muộn. Nguyên nhân gây bệnh hiện còn chưa được rõ. Các giải thuyết đưa ra gồm: vai trò của yếu tố môi trường hoặc gen và cơ chế gây chết nơron (stress oxy hóa, mất chức năng thể hạt, biến chất của protein). Trong 10 năm gần đây, người ta đã chứng minh vai trò của genes trong hội chứng Parkinson có tính chất gia đình. Điều trị chính gồm hai nhóm: điều trị nội khoa sử dụng thuốc Levodopa, đồng vận dopamine và phẫu thuật kích thích não sâu. Phẫu thuật kích thích não sâu có rất nhiều ưu điểm vượt trội: cải thiện tất cả các triệu chứng chủ yếu của Parkinson. Đánh giá hiệu quả ngắn hạn thông qua một nghiên cứu lớn của đa trung tâm với 96 bệnh nhân Parkinson nhận được điều trị kích thích nhân dưới đồi thị hai bên, trong đó 91 bệnh nhân được theo dối hoàn toàn trong 6 tháng, so với tình trạng lúc chỉ điêuu trị bằng thuốc thấy cải thiện: $44 \%$ điểm số UPDRS, $51 \%$ điểm vận động. Cụ thể: run cải thiện $79 \%$, độ cứng $58 \%$, chậm vận động $42 \%$, dáng đi $56 \%$, bất ổn định tư thế $50 \%$, nhật kí bệnh nhân thấy tăng thời gian không có rối loạn vận động từ 27-74\%, giảm thời gian nghi từ 49-19\%. Thang điểm Rush Dyskinesia Scale cho thây: cải thiện rối loạn vận động $58 \%$, giảm liều lượng dùng thuốc $37 \%$. Đánh giá hiệu quả dài hạn $(3-4$ năm theo dõi) với 49 bệnh nhân trong nhóm trên: $43 \%$ điểm số UPDRS, $50 \%$ điểm vận động. Cụ thể: run cải thiện $87 \%$, độ cứng $59 \%$, chậm vận động $42 \%$, dáng đi $41 \%$, bất ổn định tư thế $31 \%$, rối loạn vận động giảm 59\%, giảm liều levodoppa $34 \%$ so với đường cơ sở. So sánh với hiệu quả sau 1 năm đăt DBS, thì sau 3-4 năm đặt thấy hiệu quả với các triệu chứng Parkinson có giảm đi, tuy nhiên vẫn cải thiện đáng kể so với đường cơ sở không dùng thuốc.

Trên thế giới đã có nhiều nghiên cứu chứng minh tính hiệu quả của phương pháp kích thích não sâu điều trị bệnh lý Parkinson vô căn. Tuy nhiên, các nghiên cứu này còn rất hạn chế tại Việt Nam. Hiện nay có hai cơ sở tiến hành kỹ thuật này tại Việt Nam: Bệnh viện Việt Đức và Bệnh viện Y Dược thành phố Hồ Chí Minh. Chúng tôi tiến hành nghiên cứu «Đánh giá kết quả kích thich não sâu điều trị bệnh lý Parkinson vô căn tại Bệnh viện Việt Đức» với mục tiêu:

1. Mô tả đặc điểm lâm sàng và cận lâm sàng chính của bệnh lý Parkinson vồ căn.

2. Đánh giá kêt quả bước đầu của điều trị phẫu thuật kích thích não sâu điều trị bệnh lý Parkinson vô căn tại Bênh viện Viềt Đức.

\section{II. ĐỐI TƯỢNG VÀ PHƯƠNG PHÁP NGHIÊN CỨU}

1. Đối tượng nghiên cứu. Nghiên cứu đặc điểm lâm sàng của bệnh nhân Parkinson vô cẳn và được phẫu thuật kích thích não sâu tại Bệnh viện Việt Đức từ tháng $1 / 2016$ đến tháng $5 / 2020$.

Tiêu chuẩn loại trừ:

- Bệnh nhân không đủ tiêu chuẩn chẩn đoán Parkinson vô căn

- Bệnh nhân có yếu tố chống chỉ định của phẫu thuật kích thích não sâu

- Bệnh nhân chẩn đoán Parkinson vô căn nhưng đáp ứng với L-dopa thấp (dưới 33\%) hoặc thang điểm UPDRS <30 
- Bệnh nhân không đồng ý tham gia nghiên cứu

2. Phương pháp nghiên cứu. Mô tả cắt ngang, tiến cứu tất cả các trường hợp bệnh nhân được chẩn đoán Parkinson vô căn và được phẫu thuật kích thích não sâu tại Bệnh viện Việt Đức.

Chẩn đoán bệnh lý Parkinson vô căn được thực hiện quy trình như sau (áp dụng theo tiểu chuẩn của tổ chức Parkinson - nước Anh):

Bước 1: chẩn đoán hội chứng Parkinson

\section{Tiêu chuẩn bao gồm}

1. Chậm vận động (sự chậm chạp của khởi động các động tác tự chủ với tiến triển giảm về tốc độ và biên độ các động tác quen thuộc), kết hợp với 1 trong 3 tiêu chuẩn sau:

2. Cứng cơ

3. Run khi nghỉ ngơi 4-6Hz

4. Mất vững tư thế không có nguyên nhân khởi đâu do thị giác, tiền đình, tiểu não, hoặc bất thường cơ quan nhận cảm hoạt động

Bước 2: Loại trừ nguyển nhân gây bệnh Parkinson

\section{Tiêu chuẩn loai trừ}

1. Tiền sử lặp lại của đột quy. với tiến triển bậc thang Parkinson trong tương lai

2. Tiền sử lặp lại của tổn thương não

3. Tiền sử viêm não

4. Cơn rối loạn vận nhãn

5. Triệu chứng ban đầu khi bắt đầu điều trị an thần

6. Biểu hiện ở các lần liên quan đến cảm xúc

7. Suy giảm miễn dịch

8. Biểu hiện một bên sau 3 tuổi
9. Liệt trên nhân tiến triển

10. Dấu hiệu tiểu não

11. Mất tự chủ trầm trọng sớm

12. Sa sút trí tuệ trầm trọng sớm với rối loạn trí nhớ, ngôn ngữ, thói quen

13. Dấu hiện Babinsky

14. U não/giãn não thất

15. Không đáp ứng với liều rộng Levodopa

(đã loại trừ khả năng kém hấp thu)

16. Loại trừ nhiểm độc (MPTP..)

17. Bước 3: Bổ sung bằng chứng chẩn đoán Parkinson vô căn.

Tiêu chuẩn hố trợ. Tiêu chuẩn bao gồm + Từ 3 tiêu chuẩn trở lển dưới đây sẽ chẩn đoán xác định PD

1. Khởi đầu 1 bên

2. Run khi nghỉ ngơi

3. Rối loạn tiến triển

4. Sự mất đối xứng tồn tại dai dẳng nhất là

bên có triệu chứng đầu tiên

5. Đáp ứng tốt với Levodopa (70-100\%)

6. Múa giật khi liều cao Levodopa

7. Đáp ứng Levodopa từ trên 5 năm

8. Tiến triển lâm sàng từ trên 10 năm

Bệnh nhân được khám và đánh giá bằng bảng điểm UPDRS gồm 4 phần: trạng thái tâm lý (4 tiểu mục), hoạt động sinh hoạt hàng ngày (13 tiểu mục), chức năng vận động (14 tiểu mục), biến chứng của điều trị thuốc (11 tiểu mục). Mục đích đánh giá độ nhạy cảm với điều trị L-dopa. Bệnh nhân được đánh giá giai đoạn bệnh theo thang phân loại tại thời điểm « On », « Off »

\begin{tabular}{|c|c|}
\hline Giai đoạn & Mô tả \\
\hline 1.0 & Run hoặc cứng đờ chỉ một bên (có hoặc không chậm vận động) \\
\hline 1.5 & Run hoặc cứng đờ một bên và trục (có hoặc không chậm vận động) \\
\hline 2.0 & Mức độ vừa của run hoặc cứng đờ hai bên với chậm vận động nhưng không mất thăng bằng \\
\hline 2.5 & $\begin{array}{l}\text { Mức độ vừa của run hoặc cứng đờ hai bên với chậm vận động nhưng phục hồi với test } \\
\text { kéo đẩy }\end{array}$ \\
\hline 3.0 & $\begin{array}{l}\text { Mức độ đáng kể của run hoặc cứng đờ hai bên với chậm vận động và mất ổn định tư } \\
\text { thế (bệnh nhân còn tự chủ về thể chất) }\end{array}$ \\
\hline 4.0 & Khuyết tật nặng nhưng có thể đứng hoặc đi mà không cần trợ giúp \\
\hline 5.0 & $\begin{array}{l}\text { Nằm liệt giường hoặc xe lăn hoặc bị ràng buộc trừ khi có trơ giúp (bệnh nhân không có } \\
\text { hoạt động độc lập) }\end{array}$ \\
\hline
\end{tabular}

Bệnh nhân có chỉ định của phẫu thuật kích thích não sâu và không có yếu tố chống chỉ định, được đánh giá bởi hội đồng chuyên gia: phẫu thuật viên - bác sỹ nội thần kinh chuyên sâu về rối İoạn vận động - bác sỹ gây mê - kỹ thuật viên. Chỉ định phẩu thuật kích thích não sâu khi đủ các tiêu chuẩn sau:

- Tuổi tữ dưới 70

- Nằm trong tiêu chuẩn chẩn đoán bệnh lý Parkinson vô căn
- Thời gian mắc bênh trên 5 năm

- Triệu chứng vận động giai đoạn "tắt" từ trung bình - nặng (MDS-UPDRS > 30)

- Tỉ lệ đáp ứng với thuốc $\geq 33 \%$

- Xuất hiện biến chứng vận động (dao động vận động, loạn động) mức độ trung bình- nặng

- Số liều thuốc tối thiểu mỗi ngày mà vẫn có dao động vận động $\geq 4$

- Không có yếu tố chống chỉ định:

- Sa sút tâm thần trung bình - nặng (đánh 
giá qua MMSE)

- Rối loạn khí sắc nặng (lo âu, trầm cảm, ám ảnh cưỡng chế)

- Loan thần kháng thuốc

- Các phản xạ nguyên phát

- Các triệu chứng của liệt trên nhân tiến triển

- Các triệu chứng mất thực dụng

- Rối loan thần kinh tự chủ

- Các triệu chứng tiểu não

- Đang dùng thuốc chống đông máu

Bệnh nhân được đánh giá trắc nghiệm trầm cảm. Bệnh nhân được phẫu thuật đặt điện cực kích thích não sâu vị trí nhân dưới đồi thị 2 bên, « On » thuốc và « Off » máy sau mổ 2 tuần.

Bệnh nhân được đánh giá cải thiện vận động qua thang điểm UPDRS tai các thời điểm : trước mổ, sau mổ 3 tháng -6 tháng -12 tháng.

Số liệu thu thập bằng hồ sơ bệnh án chuyên sâu của bệnh nhân Parkinson, xử lý số liêu qua phần mềm SPSS 16.0, sử dụng các test thống kê.

\section{KẾT QUẢ NGHIÊN CỨU VÀ BÀN LUÂ̂N}

1. Đặc điểm lâm sàng, cận lâm sàng của bệnh nhân Parkinson vô căn

1.1. Đặc điểm chung đôi tượng nghiên cứtu

Bảng 1.1. Đặc điểm chung đôî̉ tượng nghiên cứu $(n=10)$

\begin{tabular}{|c|c|c|c|}
\hline \multicolumn{2}{|c|}{ Đặc điếm } & $\mathbf{n}$ & $\mathbf{\%}$ \\
\hline \multirow{2}{*}{$\begin{array}{c}\text { Giới } \\
\text { tính }\end{array}$} & Nam & 7 & 70,0 \\
\cline { 2 - 4 } & Nữ & 3 & 30,0 \\
\hline \multirow{4}{*}{ Tuổi } & Người lớn (50-60 tuối) & 5 & 50,0 \\
\cline { 2 - 4 } & Cao tuối (60 - 70 tuối) & 5 & 50,0 \\
\cline { 2 - 4 } & $X \pm$ SD, Min, Max & \multicolumn{2}{|c|}{$\begin{array}{c}60,6 \pm 8,5 ; \\
\min =42 ; \\
\max =70\end{array}$} \\
\hline
\end{tabular}

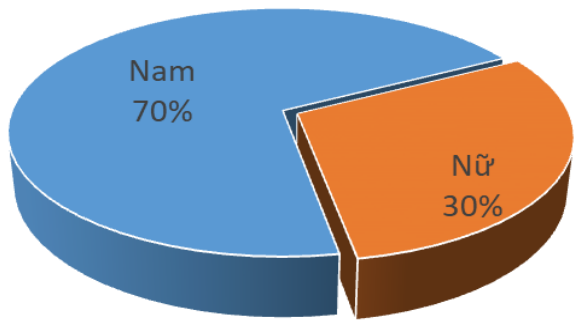

Biểu đồ 1. Phân bố bệnh nhân theo giới

Nhận xét: Bênh nhân mắc Parkinson vô căn có chỉ định phấu thuật chủ yếu là nam giới chiếm $70 \%$, tuổi trung bình mắc bệnh là 60 tuổi. Hiện nay tại Việt Nam chưa có nghiên cứu về tỉ lệ mắc mới Parkinson hàng năm, tuy nhiên, nghiên cứu tại 25 trung tâm tại Châu Âu cho thấy tỉ lệ mắc hàng năm của bệnh lý Parkinson là 4,9/10000 người, các nghiên cứu khác tại Italia là 16 - 19/10000 người, nghiên cứu tại Đài Loan là 10,4/10000 người. Trong đó giai đoạn tuổi mắc cao nhất là từ 50 - 59 tuổi, cao gấp 11 lần giai đoạn $80-99$ tuổi. Về giới tính, các nghiên cứu trên thế giới cũng cho thấy rằng nguy cơ mắc và tỉ lệ mắc Parkinson của nam giới cao hơn nữ giới [1].

1.2. Đặc điểm về triệu chứng lâm sàng

Bảng 1.2. Triêu chứng vận động $(n=10)$

\begin{tabular}{|c|c|c|}
\hline Triệu chứng lâm sàng & $\mathbf{n}$ & $\mathbf{\%}$ \\
\hline Run & 8 & 80,0 \\
\hline Đơ Cứng & 10 & 100,0 \\
\hline Chậm vận động & 7 & 70,0 \\
\hline Loạn động On - Off & 9 & 90,0 \\
\hline Mất ốn định tư thế & 10 & 100,0 \\
\hline Đông cứng & 7 & 70,0 \\
\hline
\end{tabular}

Nhận xét: Triệu chứng đơ cứng, mất ổn định tư thế gặp ở tất cả các bệnh nhân nghiên cứu. Các triệu chứng khác như: run, loạn động giai đoạn bật - tắt, đông cứng đều gặp đa số các bệnh nhân. Tuy nhiên, các triệu chứng trên đều đáp ứng với điều trị dopaminergic và theo nhiều nghiễn cứu, các triệu chứng này đều đáp ứng với phẫu thuật kích thích não sâu [2] [3].

Bảng 1.3. Thời gian diễn biến bệnh đến khi phầu thuật

\begin{tabular}{|c|c|c|}
$\begin{array}{c}\text { Thời gian diê̂n biến } \\
\text { bệnh đến phâ̂u thuật }\end{array}$ & $\mathbf{n}$ & $\%$ \\
\hline $5-9$ năm & 3 & 30,0 \\
\hline $10-15$ năm & 5 & 50,0 \\
\hline$>15$ năm & 2 & 20,0 \\
\hline$X \pm$ SD, Min, Max & \multicolumn{2}{|c|}{$\begin{array}{r}11,4 \pm 3,9 ; \text { min } \\
6 ; \text { max = 19 }\end{array}$} \\
\hline
\end{tabular}

Nhận xét: Thời gian mắc bệnh trung bình là 11 năm, trong đó hâuu hết các bệnh nhân mắc bênh từ dưới 15 năm chiếm $80 \%$. Điều này tiên lượng tốt với đáp ứng phẫu thuật kích não sâu. Nghiên cứu của tác giả Welter cho thấy tuổi mắc bệnh từ dưới 56 tuổi và thời gian kéo dài dưới 16 nắm là hai yếu tố tiên lượng đáp ứng tốt với phẫu thuật kích thích não sâu [3].

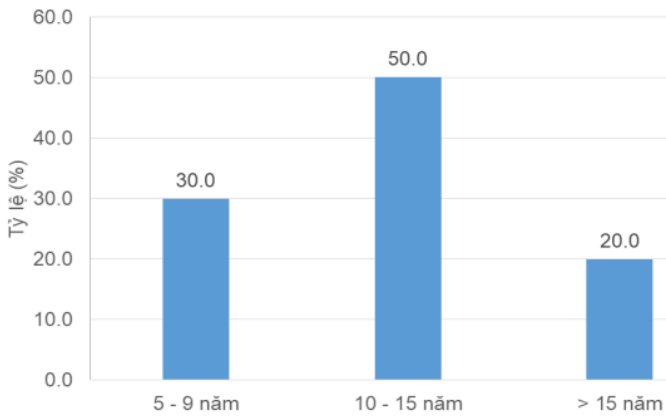

Biểu đồ 2. Phân bố theo thời gian bị bệnh đến khi phẫu thuật của bệnh nhân

Bảng 1.4. Triệu chứng lâm sàng xuất 
hiện đầu tiên ( $n=10)$

\begin{tabular}{|c|c|c|}
\hline Triệu chứng lâm sàng & $\mathbf{n}$ & $\mathbf{\%}$ \\
\hline Run & 0 & 0,0 \\
\hline Đơ Cứng & 3 & 30,0 \\
\hline Chậm vận động & 7 & 70,0 \\
\hline Loậ động On - Off & 0 & 0,0 \\
\hline Mất ốn định tư thế & 0 & 0,0 \\
\hline Đông cứng & 0 & 0,0 \\
\hline
\end{tabular}

Nhân xét: Triệu chứng lâm sàng đâu tiên xuất hiện ở phần lớn các bệnh nhân $(70 \%)$ đó là chậm vận động, thứ hai đó là đơ cứng khi vận động (30\%). Đây cũng là triệu chứng đặc trưng nhất của rối loạn chức năng hạch nền trong bệnh lý Parkinson, chậm vận động biểu hiện bằng sự chậm trễ khi bắt đầu và quá trình thựcc hiện một động tác cử động hoặc sự chậm trễ trong dừng lại một động tác, giảm biên độ và tốc độ di chuyển, lặp đi lặp lại và không có khả năng thực hiện các hoạt động đồng thời hoặc tuần tự, hoặc các biểu hiện khác như: chảy dãi do rối loạn nuốt nước bợt, rối loạn vận động đơn điệu, mất khả năng diễn đạt trên khuôn mặt, mất động tác tự động khi đi bộ (không vung được tay) [4].

1.3. Đặc điểm về đánh giá cận lâm sàng khảo sát trước mổ

Bảng 1.5. Đặc điểm về phát hiện tổn thương não trên CHT $3.0 \mathrm{~T}$ (STN: subthalamic nucleus)

\begin{tabular}{|c|c|c|}
\hline CHT 3.0T & Bên phải & Bên trái \\
\hline Tốn thương não & 0 & 0 \\
\hline $\begin{array}{c}\text { Không thấy tốn } \\
\text { thương não }\end{array}$ & $100 \%$ & $100 \%$ \\
\hline
\end{tabular}

Nhận xét: Sử dụng cộng hưởng từ (CHT) 3.0 Tesla theo protocol tiêu chuẩn để đánh giá hệ thống hạch nền và tổn thương não phối hợp, chúng tôi nhận thấy tất cả các bệnh nhân không có tổn thương não khác kèm theo trên $\mathrm{CHT}$.

1.4. Vị trí đường vào của microelectrode tìm được nhân dưới đồi trong mổ

Bảng 1.6. Vị trí đường vào của microelectrode tim được nhân STN trong mổ $(n=10)$

\begin{tabular}{|c|c|c|}
\hline & Bên phải & Bên trái \\
\hline Trung tâm (center) & $9(90,0)$ & $6(60,0)$ \\
\hline Giữa (median) & $0(0,0)$ & $3(30,0)$ \\
\hline Bên (lateral) & $1(10,0)$ & $1(10,0)$ \\
\hline Trước (anterior) & $0(0,0)$ & $0(0,0)$ \\
\hline Sau (posterior) & $0(0,0)$ & $0(0,0)$ \\
\hline Tống số & $10(100,0)$ & $10(100,0)$ \\
\hline
\end{tabular}

Nhân xét: Sử dụng phương pháp dò sóng STN trong mổ bằng microelectrode, đường vào lần đầu tiên của mồi bên (phải, trái) bắt đầu từ trung tâm (center) thì khả năng tìm được nhân dưới đồi (STN) cho bước sóng dài nhất là $90 \%$ (bên phải), 60\% (bên trái).

Bảng 1.7. Chiều dài STN thể hiện trên bước sóng điện sinh lý $(n=10)$

\begin{tabular}{|c|c|c|}
\hline Chiêuu dài SȚN & Bên phải & Bên trái \\
\hline Dưới 4mm & $0(0,0)$ & $0(0,0)$ \\
\hline Từ 4mm $-7 \mathrm{~mm}$ & $10(100,0)$ & $10(100,0)$ \\
\hline Trên $7 \mathrm{~mm}$ & $0(0,0)$ & $0(0,0)$ \\
\hline $\mathrm{X} \pm \mathrm{SD}, \mathrm{Min}$, & $4,1 \pm 0,5 ;$ & $4,9 \pm 0,6$ \\
Max & Min $=4 ;$ & Min $=4 ;$ \\
\hline Max $=5,5$ & Max $=6,5$ \\
\hline Tống số & $10(100,0)$ & $10(100,0)$ \\
\hline
\end{tabular}

Nhận xét: Sử dụng microelectrode để thăm dò bước sóng STN, bước sóng STN tìm được càng kéo dài thì vị trí đặt điện cực càng đạt tối đa về hiệu quả tác dụng. Trong nghiên cứu của chúng tồi, cho thấy tất cả các bệnh nhân có bước sóng STN được tìm thấy kéo dài từ 4 $7 \mathrm{~mm}$ trên target (mục tiêu). Kích thước trung bình của STN trong quần thể người là $9 \times 7 \times 4 \mathrm{~mm}$, để đánh giá vị trí đặt đúng của microelectrode vào STN dựa vào 3 yếu tố chính: khảo sát hình ảnh STN trên $\mathrm{CHT}$ trước mổ, chồng hình với $\mathrm{CT}$ scanner xác định toạ độ STN trong mổ; bước sóng STN được nhận diện khi thăm dò bằng microelectrode và hiệu quả của kích thích trong mổ của microelectrode với triệu chứng lâm sàng bệnh nhân (hiệu quả dương tính và tác dụng phụ âm tính) [5].

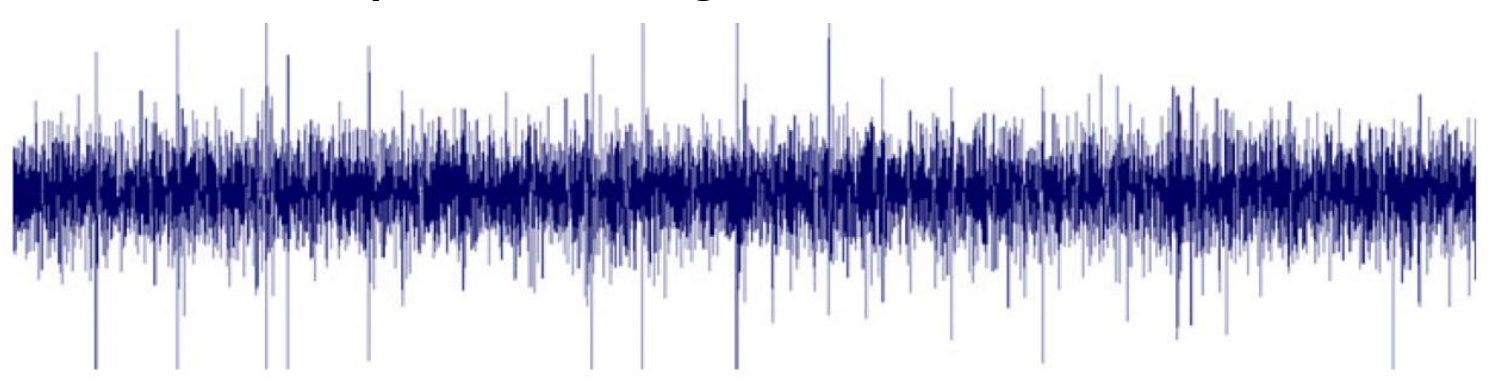

Hình 1.1. Hình dạng sóng điển hình của nhân dưới đồi thị (STN) trên thăm dò điện sinh lý thần kinh 
Bảng 1.8. Ngưỡng tác động kích thích đánh giá trong mổ $(m A)(n=10)$

\begin{tabular}{|c|c|c|}
\hline Ngưỡng kích thích $(\mathrm{mA})$ & $\mathbf{n}$ & $\mathbf{\%}$ \\
\hline Tữ dưới $7 \mathrm{~mA}$ & 9 & 90,0 \\
\hline $7 \mathrm{~mA}-9 \mathrm{~mA}$ & 1 & 10,0 \\
\hline Tống số & $\mathbf{1 0}(\mathbf{1 0 0}, \mathbf{0})$ & $\mathbf{1 0}(\mathbf{1 0 0}, \mathbf{0})$ \\
\hline
\end{tabular}

Nhận xét: Ngưỡng tác động kích thích của bênh nhân hầu hềt từ dưới $7 \mathrm{~mA}$ chiếm $90 \%$ tống số bệnh nhân phẫu thuật. $100 \%$ bệnh nhân xuất hiện tác dụng phụ nhìn đôi, tê mặt khi vượt ngưỡng kích thích.

3. Cải thiện thang điểm UPDRS trước mổ và sau mổ ( 3 tháng - 6 tháng - 12 tháng) Bảng 1.9. Cải thiện thang điểm UPDRS trước và sau mổ $(n=10)$

\begin{tabular}{|c|c|c|c|c|c|c|c|}
\hline UPDRS & $\begin{array}{c}\text { Trước phâu } \\
\text { thuật }\end{array}$ & $\begin{array}{c}\text { "Off" } \\
\text { stimulation }\end{array}$ & $\begin{array}{c}\text { "On" } \\
\text { stimulation }\end{array}$ & $\begin{array}{c}\text { Sau } \mathbf{6} \text { "Off" } \\
\text { stimulation }\end{array}$ & $\begin{array}{c}\text { "On" } \\
\text { stimulation }\end{array}$ & $\begin{array}{c}\text { Sau } 12 \text { tháng } \\
\text { stimulation }\end{array}$ & $\begin{array}{c}\text { "On" } \\
\text { stimulation }\end{array}$ \\
\hline "Off" & $67,6 \pm 2,4$ & - & - & - & - & - & - \\
\hline "On" & $30,5 \pm 5,2$ & - & $36,5 \pm 5,8$ & - & $35,5 \pm 5,4$ & - & $35,7 \pm 7,3$ \\
\hline
\end{tabular}

Nhận xét: Thang điểm đánh giá rối loạn vận động UPDRS cho thấy sự cải thiện của triệu chứng vận động sau khi phẫu thuật là cao hơn so với trước phấu thuật, đồng thời đánh giá qua 3 thời điểm sau mổ: 3 tháng, 6 tháng và 1 năm cho thấy sự cải thiện ổn định của phương pháp phẫu thuật. Kết quả nghiên cứu cũng tương đồng với các nghiên cứu đánh giá về tính hiệu quả lâu dài của phương pháp kích thích não sâu với sử dụng điện cực kích thích hai bên [6] [3]. Hơn nữa, liều levodopa sử dụng của 7/10 bệnh nhân trong nghiên cứu của chúng tôi đều được giảm $50 \%$ sau 6 tháng điều trị, $3 / 10$ bệnh nhân có thời gian hậu phẫu là trên 1 tháng cũng được giảm $25 \%$ liều thuốc levodopa. Đối chiếu với nghiên cứu mù do Anderson thực hiện cho thãy 10 bệnh nhân sau 12 tháng can thiệp được giảm liều Levodoppa $38 \%$ ở nhóm đặt kích thích nhân dưới đồi thị, 3\% ở nhóm kích thích nhân cầu nhạt [3].

4. Biến chứng gần sau mố. Trong nghiên cứu của chúng tôi ghi nhận 1 trường hợp nhiễm trùng tại vết mổ sau mổ 2 tuân và điều trị ổn định bằng kháng sinh, chăm sóc tại vết mổ. Các bệnh nhân sau mổ đều được chụp phim $\mathrm{CT}$ sọ kiểm tra có chảy máu hay không, Xq sọ và Xq ngực để kiểm tra sự liên tục và vị trí của hệ thống điện cực với bộ phát xung.

Không ghi nhận các biến chứng khác như: chảy máu, nhiễm trùng sâu (não, màng não), mất kết nối điện cực, tử vong. Các nghiên cứu trên thế giới đều ghi nhận tỉ lệ biến chứng của phẫu thuật kích thích não sâu là rất thấp, 5\% [3].

\section{KẾT LUÂNN}

Bệnh lý Parkinson vô căn gặp ở nam giới nhiêu hỡn nữ giới. Tuổi trung bình của bệnh nhân phẫu thuật kích thích não sâu là 60 tuổi. Triệu chứng lâm sàng điển hình về rối loạn vận động như: chậm vận động, cứng đơ, run, mất ổn định tư thế, loạn động, đóng băng. Các yếu tố tiên lượng tốt với đáp ứng phẫu thuật kích thích não sâu đó là: thời gian đến với phẫu thuật ngắn, tuổi khi phẫu thuật, các triệu chứng rối loạn vận động đáp ứng tốt với Levodopa, thang điểm UPDRS cải thiện ít nhất 33\%, đánh giá trong mổ với nhận diện tốt hình ảnh STN (trên $\mathrm{CHT}$ ), hoạt động kéo dài của STN (trên điện sinh lý thần kinh) và tác dung khi kích thích STN đạt hiệu quả cao, ít tác dụng phụ. Phẫu thuật kích thích não sâu hai bên nhân dưới đồi có biến chứng sau mổ rất thấp, đây là một phẫu thuật ít rủi ro. Kết quả của phấu thuật phụ thuộc vào lựa chọn bệnh nhân chặt chẽ trước mổ bằng các đánh giá lâm sàng quy chuẩn, và khảo sát hình ảnh tốt, xây dựng toạ độ mục tiêu chính xác cùng sự phối hợp đội ngũ phẫu thuật viên - bác sỹ nội - kỹ thuật viên điện sinh lý cùng sự hợp tác tốt trong giai đoạn thức tỉnh của bệnh nhân.

\section{TÀI LIÊU THAM KHẢO}

1. Michele Rajput, Alex Rajput, and Ali H. Rajput. Epidemiology. Handbook of Parkinson's disease. USA; 2007. tr 19-29.

2. Okun MS, Foote KD. Parkinson's disease DBS: what, when, who and why? The time has come to tailor DBS targets. Expert Rev Neurother. 1 Tháng Chap 2010;10(12):1847-57.

3. Keilly E. Lyons, Rajesh Pahwa. Deep Brain Stimulation. Handbook of Parkinson's disease. USA; 2007. $\operatorname{tr} 409-19$.

4. Joseph Jankovic. Pathophysiology and Clinical Assessment. Handbook of Parkinson's disease. USA; 2007. tr 49-63.

5. Ciecierski K, Raś ZW, Przybyszewski AW. Selection of the Optimal Microelectrode during DBS Surgery in Parkinson's Patients. Foundations of Intelligent Systems. Springer Berlin Heidelberg; 2011. tr 554-64. (Lecture Notes in Computer Science).

6. Schüpbach WMM, Chastan N, Welter ML, Houeto $\mathrm{JL}$, Mesnage $\mathbf{V}$, Bonnet $A M$, và c.s. Stimulation of the subthalamic nucleus in Parkinson's disease: a 5 year follow up. J Neurol Neurosurg Psychiatry. 2005;76(12):1640-4. 